\title{
Unsaturated Cuticular Hydrocarbons Synergize Responses to Sex Attractant Pheromone in the Yellow Peach Moth, Conogethes punctiferalis
}

Wei Xiao \& Shigeru Matsuyama \& Tetsu Ando \& Jocelyn G. Millar \& Hiroshi Honda

Received: 12 May 2012 / Revised: 6 July 2012 / Accepted: 9 August 2012 / Published online: 18 August 2012, J Chem Ecol (2012) 38:1143-1150, DOI 10.1007/s10886-012-0176-9

W. Xiao *: College of Plant Protection, Southwest University, 216 Tiansheng Road, Beibei, Chongqing 400715, China, e-mail: sinoshawwe@hotmail.com

S. Matsuyama, H. Honda: Graduate School of Life and Environmental Sciences, University of Tsukuba, 1-1-1, Tennodai, Tsukuba, Ibaraki 305-8572, Japan

T. Ando: Graduate School of Bio-Applications and Systems Engineering, Tokyo University of Agriculture and Technology, Koganei, Tokyo 184-8588, Japan

J. G. Millar: Department of Entomology, University of California Riverside, Riverside, CA 92521, USA

\begin{abstract}
Abstrac
t Four trienyl hydrocarbons, (Z3, Z6, Z9)-tricosatriene (Z3, Z6, Z9-23:HC), (Z3, Z6, Z9)-pentacosatriene (Z3, Z6, Z9-25:HC), (Z3, Z6, Z9)-heptacosatriene (Z3, Z6, Z9-27:HC), and (Z3, Z6, Z9)-nonacosatriene (Z3, Z6, Z9-29:HC) were identified in a non-polar fraction of the body wax of male and female yellow peach moth, Conogethes punctiferalis. The relative amounts and ratios of these hydrocarbons differed between sexes. In females, the ratios in body wax and pheromone gland extracts were similar, with lesser amounts found in gland extracts. Synergistic effects of these hydrocarbons when added to the known aldehyde pheromone components were assessed in wind tunnel tests. A blend of (E)-10-hexadecenal (E10-16: Ald) and (Z)-10-hexadecenal (Z10-16: Ald) elicited upwind flight and orientation of males to the pheromone source, but arriving males did not remain close to source for very long. Among the hydrocarbons identified, only Z3, Z6, Z9-23:HC enhanced the activity of the aldehyde blend by increasing the time spent close to the source and the number of source contacts. Z3, Z6, Z9-23:HC and (Z9)-heptacosene (Z9-27: HC) also increased close-range responses to the aldehyde blend. The activity of the aldehyde blend plus these two hydrocarbons was similar to that of crude pheromone extract. Positive dose-response relationships between the aldehyde blend and two hydrocarbon mixtures were found. The lowest doses that elicited synergism were 10-1 female equivalents (of body wax extracts) for the two hydrocarbons, and 10-2 female equivalents for the total unsaturated hydrocarbon mixture.
\end{abstract}

Keywords: Unsaturated cuticular hydrocarbons. Synergist. Sex pheromone. Lepidoptera. Crambidae. Insect pest, Short-range signal 


\section{Introduction}

The yellow peach moth, Conogethes punctiferalis (Guenée)(Lepidoptera: Crambidae), is distributed through tropical and eastern Asia and Australia, where it causes damage to many orchard, spice, and vegetable crops, including peach, chestnut, durian, citrus, papaya, cardamom, ginger, eggplant, and maize (Sekiguchi, 1974; Waterhouse, 1993). Konno et al. (1982) identified (E)-10-hexadecenal (E1016:Ald) as a sex pheromone component in pheromone glands of females, and reported a binary mixture (90:10) of E10-16:Ald and (Z)-10-hexadecenal (Z10-16:Ald) as an effective pheromone lure in field tests. These two aldehydes also were identified as sex pheromone components, with small alterations in ratios, for Chinese and Korean populations of this species (Liu et al., 1994; Jung et al., 2000). However, pheromone traps baited with this binary aldehyde blend did not perform well in some regions of Japan (Kondo et al., 2008), thus reducing the reliability of this technique thus reducing the reliability of this technique for monitoring this pest. Two additional compounds [n-hexadecanal and (E)-10-hexadecen1-ol] that elicited responses from antennae of male moths were identified in Japanese populations of this species by coupled gas chromatography-electroantennogram detection (GC-EAD). However, when added to lures containing E10-16:Ald and Z10-16:Ald, neither of these components improved the attractiveness of lures (Kimura, 2002).

We hypothesized that there might be some unknown components with low volatility that were essential to the pheromone of yellow peach moth. First, we found that non-polar fractions of pheromone gland extracts and body wax extracts of females, mixed with the aldehyde pheromone blend, synergistically enhanced male responses close to pheromone sources (Xiao and Honda, 2010). Then, using wind tunnel bioassay-driven fractionation, we found that $3 \%$ and $50 \%$ ether/hexane fractions of pheromone gland and female body wax extracts, from an $\mathrm{AgNO}_{3}$-impregnated silica gel column, increased attraction to the aldehydes. The components in the $3 \%$ ether fraction were identified as a series of homologous monounsaturated hydrocarbons, among which (Z)-9-heptacosene (Z9-27:HC) enhanced male responses at short distances from the aldehyde source. However, blends of Z9-27:HC, or the entire monoene fraction, added to the aldehydes were still not as active as blends of the aldehydes with crude extracts of female body wax (Xiao et al., 2011), suggesting that there were additional active components in the $50 \%$ ether/hexane fraction.

In this paper, we report the identification of several polyunsaturated hydrocarbons in the $50 \%$ ether/hexane fraction from analyses of male and female body wax, and extracts of pheromone glands of females, by liquid chromatography on columns of silica gel impregnated with silver nitrate. We also report the synthesis and testing of these polyunsaturated hydrocarbons and the previously identified 
monoenes as possible pheromone synergists that enhance the responses of male moths when close to an aldehyde pheromone source.

\section{Methods and Materials}

Insects A colony of yellow peach moth was started from larvae collected in chestnut fields at Ibaraki prefecture, Japan. In the laboratory, larvae were reared on an artificial diet and chestnuts or corn (Honda et al., 1979). Pupae were sexed and the sexes kept separately in cages at $25 \pm 1{ }^{\circ} \mathrm{C}, 40-60 \%$ R.H., under a 15 L: 9 D photoperiod. Adults were provided with a $10 \%$ sugar solution on cotton pads. A $15 \mathrm{~W}$ red, incandescent lamp was used for observations during the scotophase.

Preparation and Fractionation of Extracts The terminal abdominal segments including the sex pheromone glands were excised with micro-scissors from 2 to 4 d-old virgin female moths anesthetized with $\mathrm{CO}_{2}, 5-8 \mathrm{~h}$ after lights off. The abdominal tips were extracted for $15 \mathrm{~min}$ at room temperature with redistilled n-hexane (ca. $1 \boldsymbol{\mu l}$ per insect) containing $0.01 \%$ butylated hydroxytoluene (Wako PureChemical Industries Co. Ltd., Osaka, Japan) as an antioxidant. Crude pheromone extracts were pooled in screwcap vials [200 female equivalents (FE) per vial] with Teflon ${ }^{\circledR}-$ lined caps, and stored at $-20{ }^{\circ} \mathrm{C}$ until use. Body wax extracts were prepared from 2 to 4 d-old virgin females and males, which were anesthetized during the photophase (4-6 h after lights on) to avoid contamination of extracts from females with the aldehyde pheromone components. A whole insect was dipped in redistilled n-hexane for $2 \mathrm{~min}$ in a small glass vial. Body wax extracts were passed through a cotton filter in a Pasteur pipette ${ }^{\circledR}$ to remove body scales. Extracts of 200 insects were pooled in each vial, and stored at $-20{ }^{\circ} \mathrm{C}$. Crude pheromone gland extracts and body wax extracts of females and males were concentrated under a $\mathrm{N}_{2}$ stream and subjected to liquid chromatography ( $1 \mathrm{~cm}$ diam. $\AA \sim 3 \mathrm{~cm}$ long) on $1 \mathrm{~g}$ of Florisil (60-100 $\mu \mathrm{m}$ particle size, Wako Pure Chemicals) impregnated with $7 \%$ distilled water (Carroll, 1961). Extracts were successively eluted with $10 \mathrm{ml}$ each of hexane and $5 \%$ ether in hexane. The first eluate of each extract contained mainly hydrocarbons (non-polar fraction, NPF), whereas the second, slightly more polar, fraction of crude pheromone gland extracts contained E10-16:Ald and Z10-16:Ald. The NPF was further fractionated on a column, packed with $1 \mathrm{~g}$ of C-200 silica gel $(1 \mathrm{~cm}$ diam. $\AA \sim 3 \mathrm{~cm}$ long, particle size: $75-150 \mu \mathrm{m}$, Wako Pure Chemicals) impregnated with $10 \% \mathrm{AgNO}_{3}$. The column was successively eluted with $10 \mathrm{ml}$ each of hexane, 1, 3, 10, 30, and $50 \%$ ether in hexane, and finally with $10 \mathrm{ml}$ ether. Fractions were concentrated under $\mathrm{N}_{2}$ to $1 \mathrm{FE}$ (female equivalent)/ $\boldsymbol{\mu l}$ or 1 male equivalent $/ \boldsymbol{\mu l}$, and stored at $-20^{\circ} \mathrm{C}$ until use.

Analyses of Extracts Gas chromatography-mass spectrometry (GC-MS) analyses were conducted with a Hewlett-Packard 5972 mass selective detector coupled to an HP 5890 SeriesIIGC, equipped with an

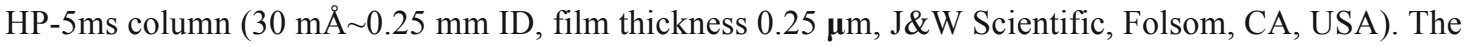


oven temperature was held at $140{ }^{\circ} \mathrm{C}$ for $2 \mathrm{~min}$, then increased to $280{ }^{\circ} \mathrm{C}$ at $5{ }^{\circ} \mathrm{C}$.min-1, and held at $280{ }^{\circ} \mathrm{C}$ for $10 \mathrm{~min}$. Samples were injected in splitless mode at $280^{\circ} \mathrm{C}$, with $\mathrm{He}$ as carrier gas. The MS interface was maintained at $280{ }^{\circ} \mathrm{C}$.

Chemicals E10-16:Ald and Z10-16:Ald were obtained from Shin-Etsu Chemical Co. Ltd. (Tokyo, Japan), and a mixture of these two aldehydes (ratio of 95.5:4.5) was prepared after purification (each $99.5 \%$ pure) by chromatography over $10 \%$ AgNO3-impregnated silica gel. (Z)-9-Tricosene (Z923:HC), (Z)-9-nonacosene (Z9-29:HC), (Z)-9-pentacosene (Z9-25:HC), Z9-27:HC, and (Z)-9-hentricontene (Z9-31: HC) were synthesized by $\mathbf{Z}$-selective Wittig reactions of the corresponding aldehydes with the C9-ylide generated by mixing KHMDS and n-nonyltriphenylphosphonium bromide, as described in Xiao et al. (2011). Four trienyl hydrocarbons were synthesized by reduction of the linolenic ester to the corresponding alcohol, followed by tosylation and chain extension with the appropriate dialkyllithium cuprates or alkylmagnesium bromides (Conner et al., 1980; Underhill et al., 1983). The synthetic triene hydrocarbons were purified on a $20 \% \mathrm{AgNO}_{3}-\mathrm{impregnated} \mathrm{silica} \mathrm{gel} \mathrm{column.}$ Purities of the trienes were confirmed to be more than $99.0 \%$ by GC-MS. (Z3, Z6, Z9)-Heptacosatriene was used as an external standard for quantification of polyene hydrocarbons in body wax and pheromone gland extracts.

Bioassays All bioassays were conducted in an acrylic wind tunnel ( $2 \mathrm{~m}$ long $\AA \sim 0.3 \mathrm{~m}$ diam.) as described in Xiao and Honda (2010). All wind tunnel tests were conducted at $25 \pm 1{ }^{\circ} \mathrm{C}$ and $40-60 \% \mathrm{RH}$ under a red incandescent light at ca. 2 lux. One $\boldsymbol{\mu l}$ of a test solution in $\mathbf{n}$-hexane was loaded on a triangular filter paper $(0.5 \mathrm{~cm}$ base $\AA \sim 1.5 \mathrm{~cm}$ height $)$, and the filter paper hung $15 \mathrm{~cm}$ above the floor and $15 \mathrm{~cm}$ from the upwind end of the wind tunnel. Two to 4-d-old males were acclimatized first in a wooden cage $(20 \AA \sim 20 \AA \sim 30 \mathrm{~cm})$ for $24 \mathrm{~h}$ and then individually in a small metal mesh cage $(6 \mathrm{~cm} \operatorname{diam} \AA \sim 6 \mathrm{~cm}$ high) for $1 \mathrm{~h}$. A cage containing a male moth was hung $15 \mathrm{~cm}$ below the ceiling at the downwind end of the wind tunnel. Male moths were allowed to leave the cage just after setting a stimulus source at the upwind end of the tunnel, and the following four behaviors recorded for 3 min: (1) flight initiation; (2) orientation to the plume (male moth flew upwind along the plume); (3) remained close to source (hovered within $10 \mathrm{~cm}$ of the source); and (4) source contact (Mazor and Dunkelblum, 1992; Xiao and Honda, 2010). The time spent close to the source and the numbers of source contacts were also recorded.

Statistical Analysis Data on initiating flight, orientating to the plume, and remaining close to the source were first analyzed by $n \AA ̊ 2$ Fisher's exact probability test using the actual number of insects. When probability was significant $(\mathbf{P}<0.05)$, multiple comparisons were performed employing Ryan's method. Data on mean time for remaining close to the source and mean numbers of source contacts by male moths were analyzed by Tukey's test. Software package R, version 2.10.0 (R Development Core Team, 2009), was used for the statistical analyses. 


\section{Results}

Identification Four major peaks (a: $19.9 \mathrm{~min}$; b: $23.1 \mathrm{~min}$; c: $26.2 \mathrm{~min}$; d: $29.0 \mathrm{~min}$; area percent of total peak area: $93 \%$ ) were detected by GC analysis of the fraction of female body wax extracts that eluted with $50 \%$ ether/hexane from an $\mathrm{AgNO}_{3}$-impregnated silica gel column (Fig. 1). The mass spectra of these compounds were similar. In each spectrum, molecular ions were observed at m/z $318\left(\mathrm{C}_{23} \mathrm{H}_{44}\right), 346$ $\left(\mathrm{C}_{25} \mathrm{H}_{48}\right), 374\left(\mathrm{C}_{27} \mathrm{H}_{52}\right)$, and $402\left(\mathrm{C}_{29} \mathrm{H}_{56}\right)$, respectively. All spectra contained ions at $\mathrm{m} / \mathrm{z} 79$ and $\mathrm{m} / \mathrm{z} 108$, which were assigned as $\left[(\mathrm{CH}=\mathrm{CH})_{3} \mathrm{H}\right]+$ and $\left[\mathrm{CH}_{3} \mathrm{CH}_{2}(\mathrm{CH}=\mathrm{CH})_{3} \mathrm{H}\right]^{+}$, respectively, and which are diagnostic for methyleneinterrupted 3,6,9-alkatriene structures (Millar, 2000). Distinct fragment ions also were observed at m/z 262, 290,318, and 346 in each spectrum, respectively, corresponding to $\mathrm{M}_{+}-56$ (loss of $\left.\mathrm{C}_{4} \mathrm{H} 8\right)$; i.e., $\left[\mathrm{H}(\mathrm{CH}=\mathrm{CH})_{3} \mathrm{C}_{13} \mathrm{H}_{27}\right]+,\left[\mathrm{H}(\mathrm{CH}=\mathrm{CH})_{3} \mathrm{C}_{15} \mathrm{H}_{31}\right]_{+},\left[\mathrm{H}(\mathrm{CH}=\mathrm{CH})_{3} \mathrm{C}_{17} \mathrm{H}_{35}\right]_{+}$, and $[\mathrm{H}(\mathrm{CH}=$ $\left.\mathrm{CH}{ }_{3} \mathrm{C}_{19} \mathrm{H}_{39}\right]_{+}$. On the basis of their mass spectra, these four compounds were tentatively identified as 3,6 , 9-tricosatriene, 3, 6, 9-pentacosatriene, 3, 6, 9-heptacosatriene, and 3, 6, 9-nonacosatriene, respectively. The shorter retention times of these compounds, compared to those of corresponding alkanes, on a non-polar column verified that none of the double bonds in these molecules were conjugated (Millar, 2000). The mass spectra and retention times of the four compounds matched those of synthetic Z3, Z6, Z9-23:HC, Z3, Z6, Z9-25:HC, Z3, Z6, Z9-27:HC, and Z3, Z6, Z9-29:HC (peaks a-d, respectively). The same trienyl hydrocarbons also were identified in the $50 \%$ ether/hexane fraction of extracts of pheromone glands of females, and in body wax extracts of male moths. The quantitative profiles of the hydrocarbons from the female body wax extracts, the pheromone gland extracts, and male body wax extracts are shown in Table 1. Ratios (as peak area percentage) of the four hydrocarbons were similar between the female body wax and pheromone gland extracts, but markedly different from male body wax extracts, which contained relatively little Z3, Z6, Z9-23:HC in comparison to the extracts from females. The total amount of triene hydrocarbons from the female body wax extracts was ca. $9.4 \mathrm{ng} / \mathrm{female}$, about 10 times more than that in pheromone gland extracts, but 37 times less than in male body wax extracts. Synergistic Effects of Unsaturated Hydrocarbons We had previously shown that the NPF of female body wax was not by itself attractive to male moths (Xiao and Honda, 2010). The results of bioassays testing for synergism between the four trienyl hydrocarbons found in the NPF of female body wax and the aldehyde sex pheromone blend are summarized in Table 2. As reported previously, the aldehyde blend alone elicited orientation of males to the pheromone source, but once attracted, males did not remain close to the source. When each of the four trienes were tested as mixtures with the aldehyde blend, the orientation behavior of males did not change. However, the number of source contacts was enhanced by the addition of Z3, Z6, Z9-23:HC. The mixture of all the trienes and the aldehyde blend also 
induced males to spendmore time close to the source, and increased the number of source contacts in comparison to the aldehyde blend alone. Although Z3, Z6, Z9-23:HC alone or the mixture of all four trienes enhanced responses to the aldehyde blend, the responses were not as high as those elicited by the non-polar fraction of female body wax extracts or crude pheromone extracts. Similar reduced responses, compared to whole extracts, had also been observed by addition of Z9-27:HC and a mixture of other monoenes (Xiao et al., 2011). Thus, we tested the effects of mixtures of the monoenes and trienes added to the aldehyde blend. As shown in Table 3, similar response rates were found among all treatments for flight initiation, orientation to the plume, and arrestment close to the source. In comparison to the aldehyde blend alone, males remained close to the source longer, and the mean number of source contacts was higher, to the combination of Z9-27:HC, Z3, Z6, Z9-23:HC and the aldehyde blend. This activity was equivalent to that of crude pheromone extracts, and to the combinations of all monoenes and Z3, Z6, Z9-23:HC with the aldehyde blend, and all monoenes and all trienes with the aldehyde blend. In the remaining treatments, i.e., the aldehydes plus all trienes without Z3, Z6, Z9-23: HC, and the aldehydes with all monoenes and trienes except Z9-27: HC and Z3, Z6, Z9-23: HC, no enhanced effect, compared to responses to the aldehyde blend alone, was found. The dose-response relationships for a mixture of Z9-27: HC, Z3, Z6, Z9-23:HC, and aldehydes, and for a mixture of all monoenes and trienes and aldehydes, were tested. Similar patterns between dose and mean time remaining close to the source, and dose and mean number of source contacts were observed, so only the relationship between dose and mean time remaining close to source is shown in Fig. 2. Thus, for the blend of Z9-27:HC, Z3, Z6, Z9-23:HC, and the aldehydes, the lowest dose that elicited an enhanced effect was 10-1 FE (of body wax extracts), whereas for the mixture of all monoenes, trienes, and aldehydes it was $10-2$ FE. No difference between responses to the two mixtures was found for doses of 10-1 FE or 1 FE. 


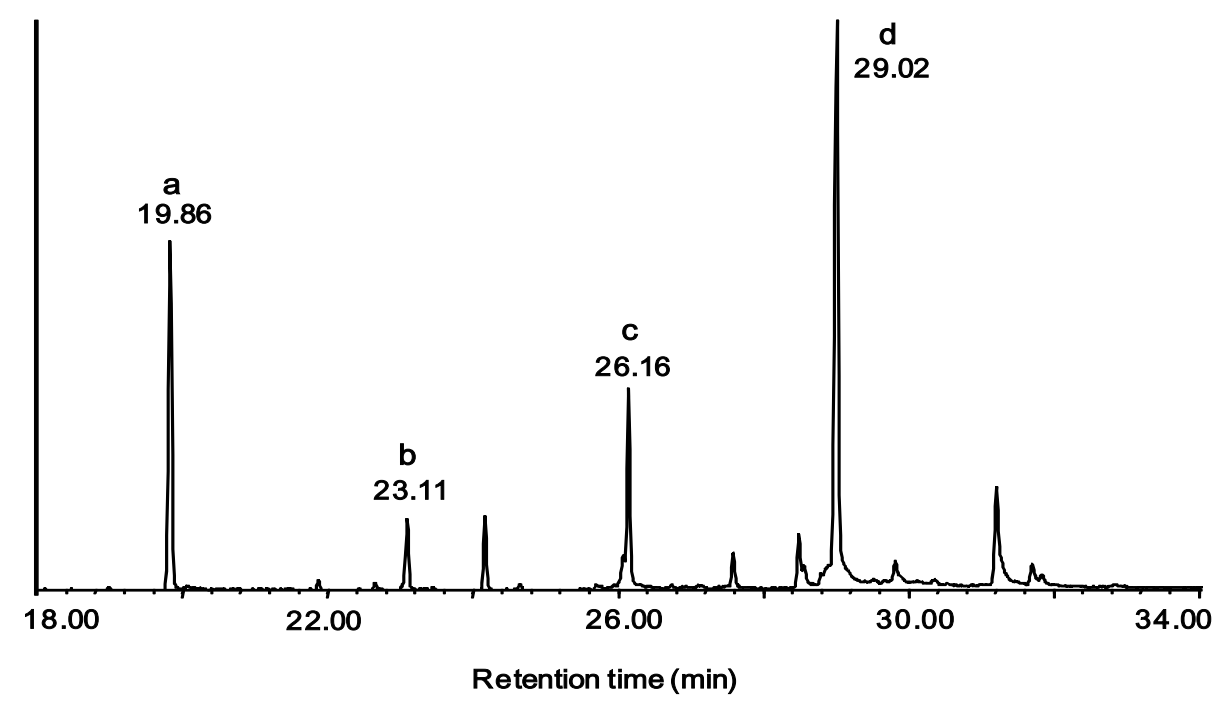

Fig. 1 Total ion chromatogram of the $50 \%$ ether/hexane fraction of the non-polar fraction of female Conogethes punctiferalis body wax extract separated on a $\mathrm{AgNO}_{3}$-impregnated silica gel column. Four major peaks (a-d) account for $93 \%$ of total peak area. Compound identities: $a=(Z 3$, Z6, Z9)-tricosatriene, b=(Z3, Z6, Z9)-pentacosatriene, $c=(Z 3, Z 6, Z 9)$-heptacosatriene, and $\mathrm{d}=(\mathrm{Z3}, \mathrm{Z6}, \mathrm{Z9})$-nonacosatriene.

Conditions: HP-5ms column $\left(30 \mathrm{~m} \AA \sim 0.25 \mathrm{~mm}\right.$ ID, $0.25 \mu \mathrm{m}$ film; $140{ }^{\circ} \mathrm{C}$ for $2 \mathrm{~min}$, then to $280{ }^{\circ} \mathrm{C}$ at $5^{\circ} \mathrm{C} \cdot \mathrm{min}-1,280^{\circ} \mathrm{C}$ for $10 \mathrm{~min}$ ). Samples were injected in splitlessly mode

Table 1 Ratios and amounts of triene hydrocarbons found in the Female Body Wax (FBW), Pheromone Gland (PG) and Male Body Wax (MBW) extracts of Conogethes punctiferalis

\begin{tabular}{|c|c|c|c|c|c|c|}
\hline \multirow{2}{*}{ Trienes } & \multicolumn{3}{|c|}{ Ratio (\%) ${ }^{a, b}$} & \multicolumn{3}{|c|}{ Amount (ng/ insect) ${ }^{a}$} \\
\hline & FBW & PG & MBW & FBW & PG & MBW \\
\hline Z3, Z6, Z9-23: HC & $25.2 \pm 0.4$ & $33.7 \pm 1.0$ & $0.1 \pm 0.0$ & $2.4 \pm 0.1$ & $0.3 \pm 0.0$ & $1.0 \pm 0.0$ \\
\hline Z3, Z6, Z9-25: HC & $7.4 \pm 0.4$ & $5.6 \pm 0.8$ & $4.6 \pm 0.1$ & $1.4 \pm 0.1$ & $0.1 \pm 0.0$ & $18.6 \pm 0.7$ \\
\hline Z3, Z6, Z9-27: HC & $27.0 \pm 1.0$ & $15.2 \pm 1.7$ & $41.4 \pm 0.4$ & $2.5 \pm 0.1$ & $0.2 \pm 0.0$ & $141.2 \pm 7.9$ \\
\hline Z3, Z6, Z9-29: HC & $40.5 \pm 1.0$ & $45.4 \pm 2.7$ & $53.9 \pm 0.3$ & & $0.3 \pm 0.0$ & $182.7 \pm 8.3$ \\
\hline Total & - & - & - & $9.4 \pm 0.4$ & $0.9 \pm 0.1$ & $343.6 \pm 16.7$ \\
\hline
\end{tabular}

${ }^{\text {a }}$ Trienes: (Z3, Z6, Z9)-tricosatriene (Z3, Z6, Z9-23:HC), (Z3, Z6, Z9)-pentacosatriene (Z3, Z6, Z9-25:HC), (Z3, Z6, Z9)-heptacosatriene (Z3, Z6,

Z9-27:HC) and (Z3, Z6, Z9)-nonacosatriene (Z3, Z6, Z9-29:HC)

${ }^{\mathrm{b}}$ Ratios are shown as the integrated peak area of each triene as a percentage of the total area of all triene hydrocarbons

${ }^{c}$ Values are shown as the mean \pm standard deviation, from 3 replicates 
Table 2 Behavioral responses of Conogethes punctiferalis males to mixtures of triene hydrocarbons plus the aldehyde blend in wind tunnel tests

\begin{tabular}{|c|c|c|c|c|c|c|}
\hline \multirow[b]{2}{*}{ Treatment $^{\mathrm{a}}$} & \multirow[t]{2}{*}{$\mathrm{N}$} & \multicolumn{3}{|c|}{ Male responses $(\%)^{c}$} & \multicolumn{2}{|c|}{ Male remaining close to source ${ }^{\mathrm{e}}$} \\
\hline & & $\begin{array}{l}\text { Initiate } \\
\text { flight }\end{array}$ & $\begin{array}{l}\text { Orientate to } \\
\text { plume }\end{array}$ & $\begin{array}{l}\text { Close to } \\
\text { source }\end{array}$ & $\begin{array}{l}\text { Mean time } \\
(\mathrm{sec})^{\mathrm{d}}\end{array}$ & $\begin{array}{l}\text { Mean number of } \\
\text { source contacts }\end{array}$ \\
\hline Z3, Z6, Z9-23: HC & 19 & $100 \mathrm{a}$ & $94.7 \mathrm{a}$ & $89.5 \mathrm{a}$ & $30.6 \pm 2.8 \mathrm{ab}$ & $11.2 \pm 1.1 \mathrm{a}$ \\
\hline Z3, Z6, Z9-25: HC & 17 & $100 \mathrm{a}$ & $94.1 \mathrm{a}$ & $94.1 \mathrm{a}$ & $16.2 \pm 2.5 \mathrm{c}$ & $5.3 \pm 1.0 \mathrm{~b}$ \\
\hline Z3, Z6, Z9-27: HC & 18 & $100 \mathrm{a}$ & 88.9 a & $88.9 \mathrm{a}$ & $17.5 \pm 2.0 \mathrm{c}$ & $5.2 \pm 0.8 \mathrm{~b}$ \\
\hline Z3, Z6, Z9-29: HC & 17 & $100 \mathrm{a}$ & $94.1 \mathrm{a}$ & $94.1 \mathrm{a}$ & $17.6 \pm 3.0 \mathrm{c}$ & $4.8 \pm 1.0 \mathrm{~b}$ \\
\hline Mixture $^{b}$ & 20 & $100 \mathrm{a}$ & $90.0 \mathrm{a}$ & $90.0 \mathrm{a}$ & $34.3 \pm 4.8 \mathrm{a}$ & $12.5 \pm 1.7 \mathrm{a}$ \\
\hline Control & 24 & $100 \mathrm{a}$ & $95.8 \mathrm{a}$ & $95.8 \mathrm{a}$ & $21.1 \pm 2.2 \mathrm{bc}$ & $6.8 \pm 0.9 \mathrm{~b}$ \\
\hline
\end{tabular}

${ }^{\mathrm{a}}$ Z3, Z6, Z9-23:HC, Z3, Z6, Z9-25:HC, Z3, Z6, Z9-27:HC and Z3, Z6, Z9-29:HC are abbreviations for (Z3, Z6, Z9)-tricosatriene, (Z3, Z6, Z9)-pentacosatriene, (Z3, Z6, Z9)-heptacosatriene and (Z3, Z6, Z9)-nonacosatriene, respectively

${ }^{\mathrm{b}}$ Ten ng (1 female equivalent) of a blend of (E)-10-hexadecenal and (Z)-10-hexadecenal at a ratio of 95.5:4.5 were added to $10 \mathrm{ng}$ each of all treatments; the control was the aldehyde blend alone ${ }^{\mathrm{c}}$ A mixture of all trienes at the natural ratio found in female body wax extracts

${ }^{\mathrm{d}}$ Data with different letters in the same column are different, $\mathbf{P}<0.05$, by Ryan's multiple comparisons after Fisher's exact probability test

${ }^{\mathrm{e}}$ Data with different letters in the same column are different, $\mathbf{P}<0.05$, by Tukey's multiple comparisons after ANOVA 
Table 3 Behavioral responses of Conogethes punctiferalis males to mixtures of the aldehyde blend, monoene and triene hydrocarbons identified in female body wax extracts

\begin{tabular}{|c|c|c|c|c|c|c|}
\hline \multirow{2}{*}{$\begin{array}{l}\text { Treatment }{ }^{\mathrm{a}, \mathrm{b}}(+ \text { aldehyde } \\
\text { blend })\end{array}$} & \multirow[b]{2}{*}{$\mathrm{N}$} & \multicolumn{3}{|c|}{ Male responses $(\%)^{\mathrm{e}}$} & \multicolumn{2}{|c|}{$\begin{array}{l}\text { Male remaining close to } \\
\text { source }^{\mathrm{e}}\end{array}$} \\
\hline & & $\begin{array}{l}\text { Initiate } \\
\text { flight }\end{array}$ & $\begin{array}{l}\text { Orientate } \\
\text { to plume }\end{array}$ & $\begin{array}{l}\text { Close to } \\
\text { source }\end{array}$ & $\begin{array}{l}\text { Mean time } \\
(\mathrm{sec})\end{array}$ & $\begin{array}{l}\text { Mean number } \\
\text { of source } \\
\text { contacts }\end{array}$ \\
\hline Z9-27:HC+Z3,Z6,Z9-23:HC & 20 & $100 \mathrm{a}$ & $95.0 \mathrm{a}$ & $95.0 \mathrm{a}$ & $94.1 \pm 8.5 \mathrm{a}$ & $40.8 \pm 3.9 \mathrm{a}$ \\
\hline $\begin{array}{l}\text { Monoenes }^{\mathrm{c}}+\mathrm{Z3}, \mathrm{Z6}, \mathrm{Z9}- \\
\text { 23:HC }\end{array}$ & 17 & $100 \mathrm{a}$ & $88.2 \mathrm{a}$ & $88.2 \mathrm{a}$ & $97.0 \pm 7.3 \mathrm{a}$ & $39.6 \pm 3.4 \mathrm{a}$ \\
\hline Monoenes $^{c}+$ Trienes $^{d}$ & 20 & $100 \mathrm{a}$ & $95.0 \mathrm{a}$ & $95.0 \mathrm{a}$ & $90.6 \pm 7.6 \mathrm{a}$ & $38.1 \pm 3.2 \mathrm{a}$ \\
\hline Crude pheromone extracts & 14 & $100 \mathrm{a}$ & $87.3 \mathrm{a}$ & $87.3 \mathrm{a}$ & $88.1 \pm 6.7 \mathrm{a}$ & $39.7 \pm 7.3 \mathrm{a}$ \\
\hline Trienes $^{\mathrm{d}}-\mathrm{Z3}, \mathrm{Z6,Z9-23:HC}$ & 16 & $100 \mathrm{a}$ & $93.8 \mathrm{a}$ & $93.8 \mathrm{a}$ & $19.7 \pm 2.8 \mathrm{~b}$ & $6.3 \pm 1.5 \mathrm{~b}$ \\
\hline $\begin{array}{l}\text { Monoenes }^{\mathrm{c}}+\text { Trienes }^{\mathrm{d}}-\mathrm{Z9}- \\
\text { 27:HC-Z3,Z6,Z9-23:HC }\end{array}$ & 19 & $100 \mathrm{a}$ & $94.7 \mathrm{a}$ & $94.7 \mathrm{a}$ & $35.6 \pm 4.0 \mathrm{~b}$ & $12.2 \pm 1.6 \mathrm{~b}$ \\
\hline Control & 19 & $100 \mathrm{a}$ & $94.7 \mathrm{a}$ & $94.7 \mathrm{a}$ & $23.4 \pm 3.0 \mathrm{~b}$ & $7.2 \pm 0.9 \mathrm{~b}$ \\
\hline
\end{tabular}

${ }^{a}$ Ten ng (1 female equivalent, FE) of a blend of (E)-10-hexadecenal and (Z)-10-hexadecenal at a ratio of 95.5:4.5 were added to all treatments (at 3FE), except that of the crude pheromone extract; the control was the aldehydes blend alone

${ }^{\mathrm{b}}$ Z9-27:HC and Z3,Z6,Z9-23:HC are abbreviations for (Z9)-heptacosene and (Z3, Z6, Z9)-tricosatriene

${ }^{c}$ Three FE of a monoenes mixture, including (Z)-9-tricosene, (Z)-9-pentacosene, (Z)-9-heptacosene, (Z)-9-nonacosene and (Z)-9-hentricontene, at the natural ratio in female body wax extracts

${ }^{\mathrm{d}}$ Three FE of a trienes mixture, including (Z3, Z6, Z9)-tricosatriene, (Z3, Z6, Z9)-pentacosatriene, $(\mathbf{Z 3}, \mathbf{Z 6}$, Z9)-heptacosatriene and $(\mathbf{Z 3}, \mathbf{Z 6}, \mathbf{Z 9})$-nonacosatriene, at the natural ratio in female body wax extracts

${ }^{\mathrm{e}}$ Data with different letters in the same column are different, $\mathbf{P}<0.05$, by Ryan's multiple comparisons after Fisher's exact probability test

${ }^{\mathrm{f}}$ Data with different letters in the same column are different, $\mathbf{P}<0.05$, by Tukey's multiple comparisons after ANOVA 


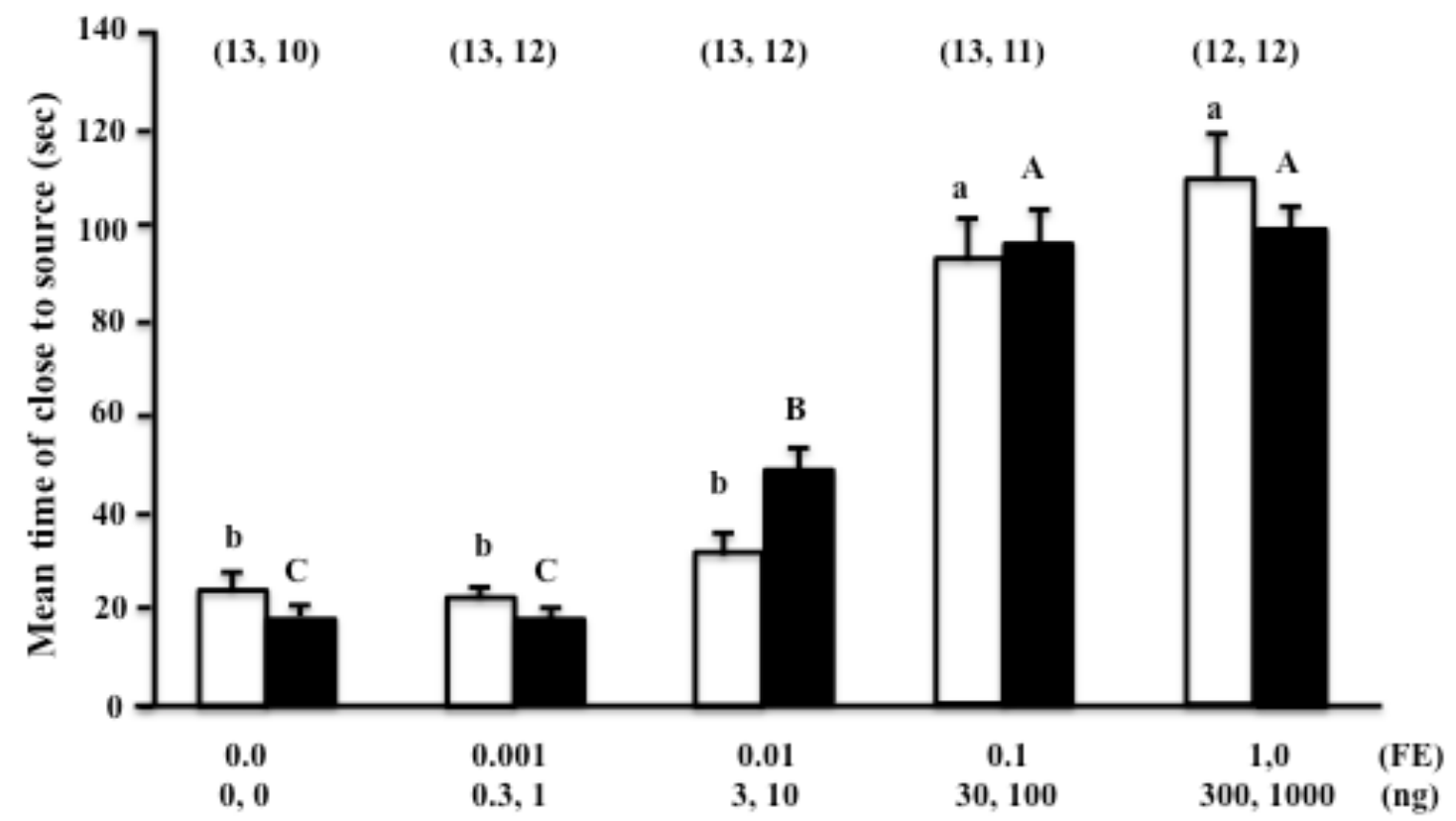

Dose of unsaturated hydrocarbons (FE, ng)

Fig. 2 Dose-response relationships of the mean time remaining close to source by males in wind tunnel tests when (Z9)-heptacosene and (Z3, Z6, Z9)-tricosatriene (open columns), or the blend of all monoenes and trienes (closed columns), were added to the aldehyde blend (10 ng). Values are shown as mean+standard error. Numbers in parentheses are the replications of different individual insects. Amounts of hydrocarbons were calculated based on female equivalents (FE) of body wax extracts. Values with the same letter were not different, $\mathbf{P}<0.05$, by Tukey's multiple comparisons after ANOVA 


\section{Discussion}

In order to improve the relatively poor performance of the pheromone lure for the yellow peach moth, we searched for new pheromone components, and showed, in wind tunnel tests, that two fractions of crude pheromone gland extract or female body wax extract enhanced short-range male responses to the standard lure of E10-16:Ald and Z10-16: Ald. We initially identified Z9-27:HC as a synergist of the aldehyde blend (Xiao et al., 2011), but bioassays demonstrated that there must be additional compounds. In the work described here, we identified a second synergist, Z3, Z6, 9Z- 23:HC. This compound and several homologs were identified as methylene-interrupted trienes. In Lepidoptera, these and related polyene hydrocarbons are probably biosynthesized in oenocyte cells from linoleic or linolenic acid precursors, leading to the production of a series of homologous polyenes with all-Z configurations, and with double bonds at the 3, 6, and 9 positions (Schal et al., 1998; Millar, 2000). Our conclusion is also supported by the fact that all of the 3,6,9-polyene hydrocarbon pheromones found to date in pyralid and crambid species have Z configurations (Cabrera et al., 2001; Millar et al., 2005; Gibb et al., 2007; Strong et al., 2008).

The same trienyl hydrocarbons also were found in male body wax extracts, but in different ratios and, with the exception of Z3, Z6, Z9-23:HC, in much larger amounts (Table 3). Qualitative or quantitative sexual dimorphism of cuticular hydrocarbons occurs widely in insects that use cuticular hydrocarbon components as recognition signals between individuals (Howard and Blomquist, 2005). Sexual dimorphism of cuticular hydrocarbons might result from genetic factors (Liimatainen and Jalon, 2007), dopamine regulation of hydrocarbon biosynthesis (Marican et al., 2004), or even differential transport of hydrocarbons by lipophorin proteins. In yellow peach moth, the factors underlying the quantitative dimorphism of trienes between males and females have not been investigated. We had previously reported that body wax extracts of female and male yellow peach moth contained the same monoene hydrocarbons (Xiao et al., 2011). Our results indicate that there is little sex specificity for most of the unsaturated hydrocarbons in body wax, but that one or more key components may be increased in females to provide a sex-specific signal. In Lepidoptera, components of female sex pheromones generally are produced in specific ratios, and even small changes in ratios may decrease or eliminate the attraction of conspecific males (Cardé and Haynes, 2004). Thus, it is entirely plausible for a component found in both sexes to be a key component of the overall sexspecific signal produced by females. In yellow peach moth, similar amounts of Z3, Z6, Z9-23:HC were found in body wax of both sexes. However, because males do not produce the aldehyde pheromone components, its presence in males is unlikely to elicit responses from other males. In addition, the amount of the trienyl hydrocarbons was much less than that of the monoene hydrocarbons identified previously (Xiao et al., 2011), although even these low amounts synergized the response to the aldehyde blend. Our dose-response experiment suggests that 
synergism by these compounds is not particularly sensitive to dose, as long as the amount is above a certain threshold.

Although Z3, Z6, Z9-23:HC synergized the aldehyde blend, its effect, or indeed the effect of the mixture of trienes, was not as high as that of the non-polar fraction of body wax extracts. The synergism of the aldehyde blend by Z9-27:HC also was lower than that of the whole non-polar fraction from female body wax extracts (Xiao et al., 2011). However, the combination of Z3, Z6, Z9-23:HC, Z9-27:HC plus the aldehyde blend was as active as crude pheromone extract (Table 3). These results indicate that the complete sex pheromone system of the yellow peach moth is composed of the two aldehyde components, E10-16:Ald and Z10-16:Ald, and at least two unsaturated hydrocarbons, Z9-27:HC and Z3, Z6, Z9-23:HC.

Lepidopteran pheromone components are classified as Type I, which includes $\mathrm{C}_{10}-\mathrm{C}_{18}$ alcohols, acetates, and aldehydes, Type II, consisting of $\mathrm{C}_{17}-\mathrm{C}_{23}$ polyunsaturated hydrocarbons or their epoxide derivatives, and a number of miscellaneous components, which are not readily classified (Millar, 2000; Ando et al., 2004). Recently, more complex systems, consisting of blends of both Type I and Type II compounds have been found as sex pheromones, or sex attractants, in some pyralid (Millar et al., 2005; Strong et al., 2008) and crambid species (Cabrera et al., 2001; Gibb et al., 2007). The yellow peach moth is a further example of a crambid species that uses both Type I (E10-16:Ald and Z1016:Ald) and Type II compounds (Z9-27:HC and Z3, Z6, Z9- 23:HC) in its pheromone. Such combinations may be a widespread motif in lepidopteran pheromone chemistry (Millar et al., 2005), and may indicate a shift in the range of compounds that constitute sex pheromone blends in Lepidoptera. Moreover, in the yellow peach moth, Z9-27:HC and Z3, Z6, Z9-23:

$\mathrm{HC}$ were in both pheromone gland extracts and body wax extracts, indicating that the alkene components are distributed over the body surface (Table 1). In Lepidoptera, Type II pheromone components are synthesized in epidermal cells and transported to the pheromone gland (Schal et al., 1998; Wei et al., 2004; Matsuoka et al., 2006; Ando et al., 2008), but there has been no report of direct evidence for specific sequestration of these hydrocarbons into pheromone glands. Because lepidopteran sex pheromone glands often occur as modified segmental membranes, between the 8th and 9th abdominal segments (Percy-Cunningham and MacDonald, 1987), pheromone gland extracts contain chemicals not only from the sex pheromone gland itself but also from associated tissues in these segments. In the yellow peach moth, the relatively small amounts of Z9-27:HC and Z3, Z6, Z9-23:HC in crude pheromone extracts may be from contamination from the cuticular hydrocarbons of the 8th and 9th abdominal segments.

Cuticular hydrocarbons are well known as chemical signals in insects, having roles in species, gender, nest mate, and caste recognition, among other functions (Howard, 1993; Howard and Blomquist, 2005). 
In Lepidoptera, potential semiochemical functions for cuticular chemicals have long been known (Ono, 1977; Rutowski, 1978; Shimizu and Tamaki, 1980). However, such cuticular hydrocarbons only appear to function as signals when presented in combination with more volatile sex attractant pheromone. For example, in the presence of the volatile sex pheromone, saturated cuticular hydrocarbons induced copulation attempts by male Orgyia leucostigma (Grant et al., 1987), or induced persistent approaches and contacts to pheromone sources by male Anarsia lineatella (Schlamp et al., 2005). In the yellow peach moth, Z9-27:HC and Z3, Z6, Z9-23:HC were not attractive to males (Xiao and Honda, 2010), but enhanced the activity of E10-16:Ald and Z10-16:Ald. This result confirms the essential role of the E10-16:Ald and Z10-16:Ald in elucidating the signal functions of Z9-27: HC and Z3, Z6, Z9-23:HC in the body wax of the yellow peach moth.

Although possible semiochemical functions of cuticular chemicals of lepidopteran species have been postulated for some time (Ono, 1977; Rutowski, 1978; Shimizu and Tamaki, 1980), the behavioral activities elicited by these compounds have generally been carried out in small spaces, such as a cage (Grant et al., 1987; Schlamp et al., 2005). Our wind-tunnel assays, with free-flying moths, provide more robust data on the synergistic functions of cuticular hydrocarbons as critical components of sex attractant pheromones.

Finally, the finding that Z9-27:HC (Xiao et al., 2011) and Z3, Z6, Z9-23:HC are close-range synergistic components of mate attraction is of fundamental importance to improving our understanding of lepidopteran pheromone systems. As described above, it is clear that, for some species at least, attraction to a long-range, volatile pheromone may be mediated over shorter distances by less volatile hydrocarbons associated with the cuticle. More careful observations of the responses of male moths of other species when close to a volatile pheromone source may reveal further examples of short-range signal components. In yellow peach moth, the poor performance of aldehyde-only pheromone lures was probably due to the absence of Z9-27:HC and Z3, Z6, Z9-23: HC, which enhance the activity of the aldehyde pheromone at shorter distances from the source. The addition of Z9-27:HC and Z3, Z6, Z9- 23:HC to the two-component aldehyde blend should induce male moths to stay near orwithin pheromone traps for a longer time, consequently increasing the likelihood of males being caught.

Acknowledgements We thank Shin-Etsu Chemical Co. Ltd. for providing E10-16: Ald and Z10-16: Ald. We also express our thanks to Prof. DeMar Taylor for reading the manuscript.

\section{References}

ANDO, T., INOMATA, S., AND YAMAMOTO, M. 2004. Lepidopteran sex pheromones. Topics Curr. Chem. 239:51-96. 
ANDO, T., KAWAI, T., AND MATSUOKA, K. 2008. Epoxyalkenyl sex pheromones produced by female moths in highly evolved groups: biosynthesis and its endocrine regulation. J. Pestic. Sci. 33:1720.

CABRERA, A., EIRAS, A. E., GRIES, G., GRIES, R., URDANETA, N., MIRÁS, B., BADJI, C., and JAFFE, K. 2001. Sex pheromone of tomato fruit borer, Neoleucinodes elegantalis. J. Chem. Ecol. 27:2097-2107.

CARDÉ, R. T. and HAYNES, K. F. 2004. Structure of the pheromone communication channels in moths, pp. 283-332, in R. T. Cardé and J. G. Millar (eds.), Advances in Insect Chemical Ecology. Cambridge University Press, New York.

CARROLL, K. K. 1961. Separation of lipid classes by chromatography on florisil. J. Lipid Res. 2:135141.

CONNER, W. E., EISNER, T., VAN DER MEER, R. K., GUERRERO, A., GHIRINGELLI, D., and MEINWALD, J. 1980. Sex attractant of an arctiid moth (Utetheisa ornatrix): a pulsed chemical signal. Behav. Ecol. Sociobiol. 7:55-63.

GIBB, A. R., PINESE, B., TENAKANAI, D., KAWI, A. P., BUNN, B., RAMANKUTTY, P., and SUCKLING, D. M. 2007. (Z)-11-Hexadecenal and (3Z, 6Z, 9Z)-tricosatriene: sex pheromone components of the red banded mango caterpillar Deanolis sublimbalis. J. Chem. Ecol. 33:579-589.

GRANT, G. G., FRECH, D., MACDONALD, L., SLESSOR, K. N., and KING, G. G. S. 1987.

Copulation releaser pheromone in body scales of female whitemarked tussock moth, Orgyia leucostigma (Lepidoptera: Lymantriidae): identification and behavioral role. J. Chem. Ecol. 13:345-356.

HONDA, H., KANEKO, J., KONNO, Y., and MATSUMOTO, Y. 1979. A simple method for massrearing of the yellow peach moth, Dichocrosis punctiferalis Guenée (Lepidoptera: Pyralidae), on an artificial diet. Appl. Entomol. Zool. 14:464-468.

HOWARD, R. W. 1993. Cuticular hydrocarbons and chemical communication, pp. 179-226, in D. W. Stanley-Samuelson and D. R. Nelson (eds.), Insect Lipids-Chemistry. Biochemistry \& Biology. Univ. Nebraska Press, Lincoln and London.

HOWARD, R. W. and BLOMQUIST, G. J. 2005. Ecological, behavioral, and biochemical aspects of insect hydrocarbons. Annu. Rev. Entomol. 50:371-393.

JUNG, J. K., HAN, K. S., CHOI, K. S., and BOO, K. S. 2000. Sex pheromone composition for field-trapping of Dichocrocis punctiferalis (Lepidoptera: Pyralidae) males. Korean J. Appl. Entomol. 39:105-110.

KIMURA, T. 2002. Chemical Ecology of Sex Pheromones in Conogethes Sibling Species. PhD dissertation. University of Tsukuba, Tsukuba.

KONDO, A., NAGATA, K., and MOCHIZUKI, F. 2008. Geographical differences in pheromone trap 
performance in the yellow peach moth, Conogethes punctiferalis (Guenée) (Lepidpptera: Pyralidae) occurring in Japanese peach orchards. Jpn. J. Appl. Entomol. Zool. Chugoku Branch. 50:35-38.

KONNO, Y., ARAI, K., SEKIGUCHI, K., and MATSUMOTO, Y. 1982. (E)- 10-Hexadecenal, a sex pheromone component of the yellow peach moth, Dichocrocis punctiferalis Guenée (Lepidoptera: Pyralidae). Appl. Entomol. Zool. 17:207-217.

LIIMATAINEN, J. O. and JALON, J.-M. 2007. Genetic analysis of cuticular hydrocarbons and their effect on courtship in Drosophila virilis and D. lummei. Behav. Genet. 37:713-725.

LIU, M. Y., TIAN, Y., and LI, Y. X. 1994. Identification of minor components of the sex pheromone of yellow peach moth, Dichocrocis punctiferalis Guenée, and field trials. Entomol. Sin. 1:150-155.

MARICAN, C., DUPORTETS, L., BIRMAN, S., and JALLON, J. M. 2004. Female-specific regulation of cuticular hydrocarbon biosynthesis by dopamine in Drosophila melanogaster. Insect Biochem. Molec. 34:823-830.

MATSUOKA, K., TABUNOKI, H., KAWAI, T., ISHIKAWA, S., YAMAMOTO, M., SATO, R., and ANDO, T. 2006. Transport of a hydrophobic biosynthetic precursor by lipophorin in the hemolymph of A geometrid female moth which secretes an epoxyalkenyl sex pheromone. Insect Biochem. Mol. Biol. $36: 576-583$.

MAZOR, M. and DUNKELBLUM, E. 1992. Role of sex pheromone components in behavioral reproductive isolation between Autographa gamma (L.) and either Trichoplusia ni (Hübner) or Chrysodeixis chalcites (Esp.) (Lepidoptera: Noctuidae: Plusiinae). J. Chem. Ecol. 18:2373-2384.

MILLAR, J. G. 2000. Polyene hydrocarbons and epoxides: second major class of lepidopteran sex attractant pheromones. Annu. Rev. Entomol. 45:575-604.

MILLAR, J. G., GRANT, G. G., MCELFRESH, J. S., STRONG, W., RUDOLPH, C., STEIN, J. D., and MOREIRA, J. A. 2005. (3Z,6Z,9Z,12Z,15Z)-Pentacosapentaene, a key pheromone component of the fir coneworm moth, Dioryctria abietivorella. J. Chem. Ecol. 31:1229-1234.

ONO, T. 1977. The scales as a releaser of the copulation attempt in Lepidoptera. Naturwissenschaften 64:386-387.

PERCY-CUNNINGHAM, J. E. and MACDONALD, J. A. 1987. Biology and ultrastructure of sex pheromone-producing cells, pp. 27-75, in G. D. Prestwich and G. J. Blomquist (eds.), Pheromone Biochemistry. Academic, Orando.

R DEVELOPMENT CORE TEAM. 2009. $\mathrm{R}$ is a language and environment for statistical computing and graphics. R Foundation for Statistical Computing, Vienna, Austria <http:/www.r-project.org>.

RUTOWSKI, R. L. 1978. The courtship behaviour of the small sulphur butterfly, Eurema lisa (Lepidoptera: Pieridae). Anim. Behav. 26:892-903.

SCHAL, C., SEVALA, V. L., and CARDÉ, R. T. 1998. Novel and highly specific transport of a volatile 
sex pheromone by hemolymph lipophorin in moths. Naturwissenschaften 85:339-342.

SCHLAMP, K. K., GRIES, R., KHASKIN, G., BROWN, K., KHASKIN, E., JUDD, G. J. R., and GRIES, G. 2005. Pheromone components from body scales of female Anarsia lineatella induce contacts by conspecific males. J. Chem. Ecol. 31:2897-2911.

SEKIGUCHI, K. 1974. Morphology, biology and control of the yellow peach moth, Dichocrosis punctiferalis Guenée (Lepidoptera: Pyralidae). Bull. Ibaraki Hort. Expt. Stn. Special Issue (in Japanese with English summery). 89.

SHIMIZU, K. and TAMAKI, Y. 1980. Releasers of male copulatory attempt in the smaller tea tortrix moth (Lepidoptera: Tortricidae). Appl. Entomol. Zool. 15:140-150.

STRONG, W. B., MILlAR, J. G., GRANT, G. G., MOREIRA, J. A., CHONG, J. M., and RUDOLPH, C. 2008. Optimization of pheromone lure and trap design for monitoring the fir coneworm, Dioryctria abietivorella. Entomol. Exp. Appl. 126:67-77.

UNDERHILL, E. W., PALANISWAMY, P., ABRAMS, S. R., BAILEY, B. K., STECK, W. F., and CHISHOLM, M. D. 1983. Triunsaturated hydrocarbons, sex pheromone components of Caenurgina erechtea. J. Chem. Ecol. 9:1413-1423.

WATERHOUSE, D. F. 1993. pp. 141, The Major Arthropod Pests and Weeds of Agriculture in Southeast Asia: Distribution, Importance and Origin. ACIAR Monograph No. 21, Camberra.

WEI,W., YAMAMOTO, M., ASATO, T., FUJII, T., PU, G. Q., and ANDO, T. 2004. Selectivity and neuroendocrine regulation of the precursor uptake by pheromone glands from hemolymph in geometrid female moths, which secrete epoxyalkenyl sex pheromones. Insect Biochem. Mol. Biol 34:1215-1224. XIAO, W. and HONDA, H. 2010. Non-polar body waxes enhance sex pheromone activity in the yellow peach moth, Conogethes punctiferalis (Guenée) (Lepidoptera: Crambidae). Appl. Entomol. Zool. 45: $449-456$.

XIAO, W., HONDA, H., AND MATSUYAMA, S. 2011. Monoenyl hydrocarbons in female body wax of the yellow peach moth as synergists of aldehyde pheromone components. Appl. Entomol. Zool.46: 239246. 